\title{
A REVIEW ARTICLE ON ROLE OF ARSHOGNA MAHAKASHAYA IN THE TREATMENT OF SUSKH ARSHA
}

\author{
Dr. Sheetal Sharma ${ }^{*}$ 区 iD, Dr. Preeti Sujit Borkar ${ }^{2}$ \\ ${ }^{* 1}$ Associate Professor, Department of Samhita \& Siddhant, SLN Ayurvedic College Amritsar, \\ Punjab, India \\ 2 Professor and Head, PG and Phd Guide, Faculty of Ayurveda, MGACH \& RC, Datta Meghe Institute \\ of Medical Sciences, Sawangi (Meghe), Wardha (M.S.), India
}

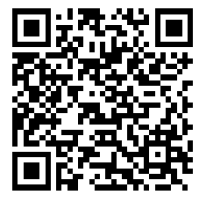

DOI: https://doi.org/10.29121/granthaalayah.v8.i10.2020.2274

Article Type: Review Article

Article Citation: Dr. Sheetal Sharma, and Dr. Preeti Sujit Borkar. (2020). A REVIEW ARTICLE ON ROLE OF ARSHOGNA MAHAKASHAYA IN THE TREATMENT OF SUSKH ARSHA. International Journal of Research GRANTHAALAYAH, 8(10), 328-332. https://doi.org/10.29121/granthaa layah.v8.i10.2020.2274

Received Date: 30 October 2020

Accepted Date: 12 November 2020

Keywords:

Arshoghan Mahakashaya

Sushka Arsha

Bheshaj Chikitsa

\section{ABSTRACT}

Ayurvedic classical text provide unique modalities and medications among several treatises complied during ancient time. Drug is the important therapeutics as it is responsible for equilibrium of whole body. Charak Samhitha is divided into 8 parts and the first division is called Sutrasthan or shloksthan. In sutrasthan the drugs are discussed in four chapters which are popularly known as Bheshajachatushka or Aushadhachatushkha. Here the drugs are classified from pharmacological and pharmacotherapeutics perspectives. The classification of drugs based on Karmas are called Mahakashaya which are classified into fifty groups. Arshoghan Mahakashaya is the twelveth group of medicine which are said to be effective in curing piles.

Sushka arsha is condition where pain and swelling of the pile mass makes life miserable for a person and bheshaj chikitsa being first in all the treatments. Here a simple effort is made to know the probable working of rasa, guna virya and prabhav of these ten drugs in dissolving the pathology of suskha arsha.

\section{INTRODUCTION}

The drugs are tools of physician. The rational use of drugs means that the half of the treatment is done. In ayurvedic classics there are lot of single and compound drugs which are mentioned in several contexts. Most of them are not retested according to the current research methodology. Unless the drug is tested through this methodology it will not get proper recognition in the scientific world. The logical application of these spectra according to the different stages and conditions of the patient and disease is the prime key of suitability of that drug in a given disease. Considering the importance of drug in disease management, Acharya Charak mentioned drug as second important factor in Chikitsachatuspad. Also, in Shalya Tantra which is one of the important branch of Ayurveda describes the six important and major principles of management of Arsh. They are Bhaisaja, KsharaKarma, YantraKarma, Agni Karma, Rakthmokshan and ShastraKarma. BhaisajaKarma is the first line of treatment.

According to Ayurveda the disease comes under the heading of Maharogas as it is Drighkalanubandhi, Dushchikitsyain nature and tridosh. It is well known for its chronicity. Arsha is being described by all classics of Ayurveda. AcharyaSushruta and Vagbhat even placed this arsha in the ASHTA MAHAGADA.[1]

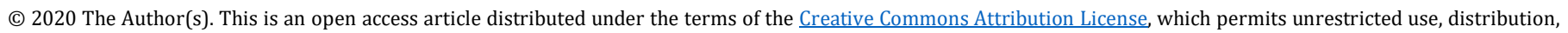
and reproduction in any medium, provided the original author and source are credited. 
Arsha pertains to a disease occurring in Guda and it is torturing the patient. It may cause obstructions of anorectal passage.[2]

According to Acharya Charak only mass at Gudavali is termed as Arsha and those at other place then Gudavali are Adhimansa [3]. According to Charak medha, mamsa, twacha is the adhisthan of Arsha.[4]

Despite so many advances in the medical science the disease piles still remain a challenge to science as no specific surgical method or other medication has proven complete remedy to cure piles. Modern medicines just give symptomatic treatment to any clinical condition of piles i.e analgesics , antibiotics, local anaesthetics, laxatives etc. which cures the symptoms but totally neglects the pathology and sooner or later these kind of patients with due course of time turn out to be operative cases of disease.

In modern era piles are mostly considered to be cured radically i.e. surgically or Para surgically procedures. These techniques are always associated with one or other type of complication which has compelled scholars to think over new, safe and better type of treatment.

The arsha which are on viserjani and not more than a year back can be treated.[5]

AcharyaCharak has emphasized the importance of oral medication in initial stages of piles sand has given a very clear foresight of the hazardous complications of Agni Karma, ShastraKarma and KsharKarma in his treatise[6] and advocates the management of arsh by oral medication and various external applications and considers this mode of therapy to be much safer and non-relapsing.[7]

Arsha is a tridoshajvikar which makes life miserable which cause lot of complications by causing different diseases and become difficult to treat.[8]

The modern medical science accepts the implementation of systemic and local measures in early stage of piles.

To find out safe, effective and low-cost therapy that covers various clinical conditions of piles and reduces the rate of haemorrhoidectomy and other parasurgical procedures and also gives complete treatment of piles in early stages is the need of hour.

Every drug and disease should be studied with a scientific approach and chapter of controversy should be solved as early as possible. Considering all these points in mind Charakokta Arshogna Mahakashaya[9] indicated for arsh management in chapter four of CharakSamhita was selected for present study. Drugs of Charakokta Arshogna Mahakashaya are easily available all over India. Present study is a review study where an attempt is made to know the Rasapanchaka working of drugs of Arshoghan Mahakashaya.

\section{DRUG REVIEW}

Arshoghan Mahakashaya is a group of ten drugs, has been described by Charak in sutrasthan chapter 4 (kshadvirechanshatashritiyaaddhaya).[10]

Bioenergetics of Drug of Arshoghana Mahakashaya.

\begin{tabular}{|c|c|c|c|c|c|c|}
\hline Sr. No. & Ingredients & Latin Name & Gunas & Ras & Virya & Vipak \\
\hline 1. & kutaj & Holerrhenaantidysentrica & Laghuruksha & $\begin{array}{l}\text { Tikta,katu, } \\
\text { kashaya }\end{array}$ & sheet & katu \\
\hline 2. & $\begin{array}{c}\text { Bilwa } \\
\text { 1.bal } \\
\text { 2.pakwa }\end{array}$ & Aeglemarmelos & $\begin{array}{c}\text { Laghu, } \\
\text { snighdha, } \\
\text { tishna, } \\
\text { Guru,ruksha }\end{array}$ & $\begin{array}{c}\text { Katu,tikta, } \\
\text { kashay } \\
\text { Katu, } \\
\text { tikta,kashay }\end{array}$ & $\begin{array}{l}\text { ushna } \\
\text { ushna }\end{array}$ & $\begin{array}{l}\text { katu } \\
\text { katu }\end{array}$ \\
\hline 3. & Chitrak & Plumbagozeylanica & $\begin{array}{l}\text { Laghu,ruksh, } \\
\text { Tikshna }\end{array}$ & katu & ushna & katu \\
\hline 4. & Nagar & Zingibarofficinale & Laghu,snigdha & katu & ushna & madhur \\
\hline 5 & Atiwisha & Aconitum heterophyllum & Laghu,ruksha, & tikta & ushna & katu \\
\hline 6. & Abhaya & Terminaliachebula & Laghu,ruksha, & panchrasa & ushna & madhur \\
\hline 7 & Dhanvyas & Fagoniaarabica & Laghu,snigdha, & $\begin{array}{l}\text { Madhur, } \\
\text { tikta, } \\
\text { kashaya }\end{array}$ & sheet & madhur \\
\hline
\end{tabular}


A Review Article on Role of Arshogna Mahakashaya in The Treatment of Suskh Arsha

\begin{tabular}{|c|c|c|c|c|c|c|}
\hline 8. & Daruharidra & Berberis species & Laghu,ruksha & $\begin{array}{c}\text { Tikta, } \\
\text { kashay }\end{array}$ & $\begin{array}{c}\text { UshnaFal- } \\
\text { sheet }\end{array}$ & katu \\
\hline 9. & Vacha & Acoruscalamus & Laghu,tikshna,sar & Tikta,katu & Ushna & katu \\
\hline 10 & Chavya & $\begin{array}{c}\text { Piper } \\
\text { chaba hunter }\end{array}$ & Laghu,ruksha, & Katu & ushna & katu \\
\hline
\end{tabular}

\section{DISCUSSION}

There are six Rasas Madhura, Amala, Lavana, Katu, Tikka, Kasahaya except lavan, all five rasas are considered as a source of kasahaya. Kasahaya is considered basically a pharmaceutical process which converts the crude drugs from its original form into another form. Raw drug has to be purified and transformed into a useful and an agreeable form so that it can be used as medicine. There are the Aausadha Kalpanas. Panchvida Kashaya Kalpanas are primary and internal kalpanas.[11] They include swarasa, Kalka, Shrita, Sheeta and Phanta. In shrita, sheet and phanta, water is the media and main aim of these kalpanas is to extract all the active principles of the raw drugs into water and by doing so the sara bagha of dravays get dissolved in water and kitta bhaga is thrown out after filtration. While describing the qualities of drugs Acharya Charak said they should be easily available and can be used in maximum ways and must contain all the active principles.[12] And these active principle are filtered from the raw drug when we make a Kashaya preparation. These Charaka drugs exercise their action by virtue of their rasa, some by guna, some by veerya and some by vipaka.[13]

The grouped drugs in Arshoghna Mahakasaya are Arshogna i.e they work against the pathology of arsha. A drug acts in accordance with its Raspanchaka in dissolving disease pathology but when used in combination; they collectively aim at one target i.e the stability in the doshas, which are vitiated because of numerous causes.

Arshoghna Mahakasaya has been framed to target only Arsha by Acharya Charaka. Being Aapta Vachana; we follow this, and it works. Here in this review only on attempt is made to know the raspanchakas working of Arshoghna Mahakashaya on Sushka Arsh only.[14]

While mentioning the treatment, Acharaya Charaka divided Arsha into two main groups:

Sushka Arsha $\quad$ One with Vaata and Kapha dominance.

Stravi Arsha One with pitta and Rakta dominance.

One with Vaata and Kapha dominance is Sushka Arsha and has following Sthanik Lakanas

- Kthorta (Hardness)

- Rukshta (Dryness)

- Shoth (Sweeling)

- Vedana (Pain)

Along with mandagni and malavibandha.

considering the dosha dominance of Arshoghna Mahakashaya maximum drugs are Vaata and kapha Shamak which will provide vyadhi prataynik effect.

$\begin{array}{ll}\text { Bilwa } & \text { Vaata Kapha Shamak } \\ \text { Chitrak } & \text { VaataKapha Shamak } \\ \text { Shunti } & \text { VaataKapha Shamak } \\ \text { Atiwisha } & \text { Tridosh Shamak } \\ \text { Haritaki } & \text { Tridosh Shamak (mainly VaataKaapha shamak) } \\ \text { Vacha } & \text { Vaatakapha shamak } \\ \text { Daruharid } & \text { VaataKaapha Shamak } \\ \text { Chavya } & \text { VaataKaapha Shamak }\end{array}$


Mandagni is the main symptom in Arsha and it is to be treated by Depana and Pachana, this action in Arsha is achieved by Chitrak and Aadrak. Both belongs to Deepaniya gana. The tikshna, laghu riksha gun corrects mandagni (Chitrak) and tikshna and katu ras (Aadrak) also clears the accumulated aam and corrects mandagni.

Vataanulomana is totally disturbed in Arsha which is the cause of malavibandha, the therapeutic effect of vaataanulomna is achieved by purgative action of haritaki which lessens the pressure on rectal veins, thus relieving symptoms of malavibandha, gudashoola and gudashotha. [15]

Chitrak, Ativisha, Daruharidra, Vacha are part of leekaniya gana. So, the collective action of these drugs of Arstroghan Mahakasaya will bring marked reduction in the size of masankur thus reducing the sthanik shoth of gudu.

Also, chitrak and Aaadrak are part of School Prashaman gana; and their working is breaking the pain pathology.

So, it is clear that all drugs of Ashtroghna Makakashaya have a specific target to the dissolve the whole pathology and bring back the stability of diseased part. [16]

\section{CONCLUSION}

In Arshoghna Mahakasaya, all drugs worked together to fight against the symptoms Suksha Arsha and ultimately very dominantly conquering over, all the symptoms like Malvibanda, Shoth, Vedana, Rukshta of arsa at guda.

\section{SOURCES OF FUNDING}

This research received no specific grant from any funding agency in the public, commercial, or not-for-profit sectors.

\section{CONFLICT OF INTEREST}

The authors have declared that no competing interests exist.

\section{ACKNOWLEDGMENT}

None.

\section{REFERENCES}

[1] Dr. Brahmanand Tripathi editor. reprinted Astanga Hridayam of Vagbhatta Nidana Sthan 8/30 Varanasi Chaukhamba Surbharati Prakashan (2007), P.no 339.

[2] Dr. Brahmanand Tripathi editor Charak Samhita Chiktisha Sthan 14/32 Varanasi Chaukhamba Surbharati Prakashan (2007), p.no 331.

[3] Dr. Brahmanand Tripathi editor Charak Samhita Chiktisha Sthan 14/6 Varanasi Chaukhamba Surbharati Prakashan (2007), p.no 509.

[4] Dr. Brahmanand Tripathi editor Charak Samhita Chiktisha Sthan $14 \backslash 6$ Varanasi Chaukhamba Surbharati Prakashan (2007), p.no 517.

[5] Dr. Brahmanand Tripathi editor Charak Samhita Chiktisha Sthan14\30 Varanasi Chaukhamba Surbharati Prakashan (2007), p.no 518.

[6] Dr. Brahmanand Tripathi editor Charak Samhita Chiktisha Sthan14\33-34 Varanasi Chaukhamba Surbharati Prakashan (2007), P.no518.

[7] Dr. Brahmanand Tripathi editor Charak Samhita Chiktisha Sthan $14 \backslash 37$ Varanasi Chaukhamba Surbharati Prakashan (2007), p.no. 519.

[8] Dr. Brahmanand Tripathi editor Charak Samhita Chiktisha Sthan14\24-25 Varanasi Chaukhamba Surbharati Prakashan (2007), p.no. 516.

[9] Dr. Brahmanand Tripathi editor Charak Samhita sutra Sthan4\12 Varanasi Chaukhamba Surbharati Prakashan (2007), p.no. 76.

[10] Dr. Brahmanand Tripathi editor Charak Samhita sutra Sthan4\8 Varanasi Chaukhamba Surbharati Prakashan (2007), p.no. 77. 
[11] Dr. Brahmanand Tripathi editor Sarngadhara Samhita Dipika Hindi Commentary) Madham Khand 2.1.

[12] Dr. Brahmanand Tripathi editor Charak Samhita sutra Sthan9\7 Varanasi Chaukhamba Surbharati Prakashan (2007), p.no. 209.

[13] Dr. Brahmanand Tripathi editor Charak Samhita sutra Sthan 26\13Varanasi Chaukhamba Surbharati Prakashan (2007), p.no. 472.

[14] Dr. Brahmanand Tripathi editor Charak Samhita Chiktisha Sthan Varanasi Chaukhamba Surbharati Prakashan (2007), p.no. 519.

[15] Dr. Brahmanand Tripathi editor Charak Samhita Chiktisha Sthan Varanasi Chaukhamba Surbharati Prakashan (2007), p.no. 519.

[16] Dr. Brahmanand Tripathi editor CharakSamhita Chiktisha Sthan Varanasi Chaukhamba Surbharati Prakashan (2007), p.no. 102. 